\title{
Success with succession: an empirical study of small Swedish family firms
}

\author{
Luleå University of Technology, \\ 97187 Luleå, Sweden \\ Fax: +46920492849 \\ E-mail: Anna.k.vikstrom@ltu.se \\ E-mail: Mats.westerberg@ltu.se \\ *Corresponding author
}

Anna Vikström* and Mats Westerberg

\begin{abstract}
Successful succession in small family firms may be a key to sustainability for the individual firm but also to regional growth. This paper examines how leadership succession factors associated to attitudes, norms and perceived behavioural control of leading actors in a small family firm can be related to how well the succession process works and to the firm's post-transition performance. We structure factors pointed out in earlier studies according to Ajzen's theory of planned behaviour (TpB) where we put forward hypotheses for the three areas. The results based on a survey of 55 small family firms that have experienced a leadership succession show that TpB works well for understanding a successful succession process, but is dismal for understanding post-transition performance. The strongest results are found for aspects linked to perceived behavioural control and attitudes.
\end{abstract}

Keywords: succession; succession process; family firm; planning; theory of planned behaviour; firm performance; Sweden.

Reference to this paper should be made as follows: Vikström, A. and Westerberg, M. (xxxx) 'Success with succession: an empirical study of small Swedish family firms', Int. J. Entrepreneurship and Small Business, Vol. X, No. Y, pp.000-000.

Biographical notes: Anna Vikström is a Lecturer in Management Control at Luleå University of Technology. Her research interest is family firms, succession and what constitutes and differentiates a family firm from other firms.

Mats Westerberg is an Assistant Professor of Entrepreneurship at Luleå University of Technology. He has published his research in several academic journals and in scientific anthologies. His current research interests are on management and entrepreneurship issues in SMEs with special focus on the entrepreneur's role for success and how the network around the firm influences the firm. He has started and run several small businesses with his wife. 


\section{Introduction}

Since small firms are of great importance for the economy (Gersick et al., 1997) and a majority of small firms are family firms (Bridge et al., 1998, Emling, 2000, NUTEK, 2004), it becomes clear that more knowledge about family firms may be important for both policy makers and academics. Despite that many have great confidence in family firms as engines for national growth (Neubauer and Lank, 1998), studies show that few family firms carry on for more than one generation (Fox et al., 1996; Lansberg, 1999), indicating that the succession issue may be a fruitful area of inquiry when studying small family firms.

Prior research (e.g., Morris et al., 1997) has pointed out some important factors for a successful succession. One key factor group is linked to the individuals involved in the succession, where both incumbents and successors have important roles in the succession. Interestingly, earlier studies have found that both parties tend to attribute more importance to the other party's role (Sharma et al., 2003a). It is clear that factors linked to the key actors may be of great importance for understanding the outcome of a succession (Hall, 2003; Miller et al., 2003; Moores and Barrett, 2002; Sharma et al., 2003a, 2003b; Venter et al., 2005). Therefore, Ajzen's (1991) theory of planned behaviour (TpB), which is closely linked to the individual, seems appropriate as a framework for explaining successful successions.

In Ajzen's theory, intentions and actual behaviour are explained by three dimensions, namely attitudes, norms, and perceived behavioural control. Regarding leadership successions, Ajzen's theory can be explained as follows: A more positive attitude and norm as well as a higher perceived behavioural control regarding issues related to succession have a positive effect on the outcome of a leadership succession. From earlier studies, all three dimensions emerge as important. For instance, the attitude to succession planning is often mentioned as an influential factor for a successful succession (Neubauer and Lank, 1998; Ward, 1987). Related to norms, trust and communication among family members is highlighted (Morris et al, 1997), as well as the importance of family members' involvement in questions concerning succession (Dyck et al., 2002; Hubler, 1999). Regarding behavioural control, factors related to the leader's self-efficacy is often found as an important factor for successful successions (Sharma, 2004).

The present study contributes to the literature on small family firm succession by explaining how factors associated to attitudes, norms and perceived behavioural control of the actors in the small family firm, can be related - independently and together - to how well a small family firm can carry out a succession both in terms of succession process and in terms of post-transition performance.

The next section describes the theoretical framework where hypotheses are generated on the link between attitudes, norms as well as perceived behavioural control and succession performance. Then, in the method section, we describe how the data was collected and analysed. The results are then presented, discussed and finally conclusions are drawn. 


\section{Theory and hypotheses}

\subsection{Family firms, successions and success}

We define a family firm as a firm where

1 at least one member from a family owns the firm

2 at least one member from the same family is active in managing daily activities in the firm

3 the leading actor in the firm regards the firm as a family firm.

Thus, we require control of ownership, active participation in management of the firm and an experienced family firm identity to consider it to be a family firm.

Based on this definition, there will be important differences between family firms and non-family firms. First, there is the potential conflict between the family and the firm. In a family firm, the managers need to balance interests of the family with interests of the firm. Owners of smaller family firms seem to handle this well since they are aware of the conflict and keep it on a reasonable level (Lee and Rogoff, 1996) and they also appreciate and value this balancing act. Related to this is the issue of decision processes, where in family firms, the family is often involved in decision-making. Handler (1990) points out that the founder/owner is the central and presumably only family member in the firm when a firm is newly established. These firms do not always see themselves as family firms. The family firm identity instead gets established when the firm grows and the power remains within the family. In other growing firms, the power can be spread outside the family, which then makes it a non-family firm.

We define succession as synonymous to leadership succession, and thus transfer of ownership is not focused in our study. The succession process can be described as a process in different stages and the starting point could be as soon as the discussion about the incumbent's retirement starts. The process can be both very demanding and also a long-term process involving multiple activities (Hall, 2003; Moores and Barrett, 2002; Sharma et al., 2003b). The process is neither an occasional nor an individual activity; rather it is often a complex process continuing for a long period (Handler, 1990; Le Breton-Miller et al., 2004). When the incumbent transfers the leadership to the successor the actual transition has occurred. The succession process can vary in length and the starting point can be close or far away from the final transition. The succession process and the final transition are influenced by factors related to either the incumbent or the successor, or factors common for both parties.

A successful family firm is one which can create prerequisites for long-term survival. These firms are more flexible and adapt its culture to the changes in the world around them. The family firm that survives in a long-term perspective has leaders who can predict trends in the business culture and who can prepare their firms and families so they can adjust to a changeable world (Dyer, 1986). It is clear that in order to fulfil a long-term survival, actors in a family firm, apart from the above, also need to be able to perform a succession from one generation to the next. 


\subsection{Important factors structured by Ajzen's theory of planned behaviour}

In this study, Ajzen's TpB has been used to structure factors important for the succession process leading up to the final transition. The succession process can be described as planned, no matter the degree of formal planning within the firm or family. When the major actors in a succession discuss the subject and come to an agreement about things to do, planning is in fact carried out. Thus, we are interested in all forms of planning, regardless whether it is written or oral, formal or informal. There will probably be someone initiating the process. The attitudes and norms concerning the final transition influence the process and the final transition. Ajzen (1991) points out the difficulty of explaining behaviour in a complex situation and asserts that attitudes, norms and expectations are factors influencing the intention to carry out an action. As mentioned earlier in this paper, we assume that a more positive attitude and norm as well as a higher perceived behavioural control regarding issues related to succession have a positive effect on the outcome of leadership succession. We will next go into details regarding these links.

\section{Attitude of the incumbent concerning succession}

An attitude reflects how important an individual considers an action to be or whether the individual supposes that the action will lead to something desirable. The attitude is based upon the individual's general idea of the likely consequences of the action (Ajzen, 1991).

Raising the succession-question within the family could be a very sensitive subject since it is somewhat taboo to discuss matters that could be related to death. Some owners of family firms seem to believe that death is something happening only to others (Kets de Vries, 1993). It is probably much easier for the incumbent, rather than the possible successors, to raise such a question. The younger generations may want to avoid questions concerning a future succession since it is connected to a fear of parental death, separation and abandonment (Lansberg, 1988). Moreover, if the possible successors start the process, the incumbent may become reluctant and resist talking about the future in terms of a possible leadership succession. Therefore, it is important that the incumbent leader has a positive attitude to starting this process at a relatively early stage. Thus, we argue that if the succession is to be successful it is important that the incumbent leader has a positive attitude to initiate the transition which leads to the following hypotheses:

H1a In family firms where the incumbent leader has a more positive attitude to initiate a transition of leadership, the process before the transition is more successful.

H1b In family firms where the incumbent leader has a more positive attitude to initiate a transition of leadership, the firm's post-transition performance is higher.

At the same time as many authors (see, Emling, 2000; Gersick et al., 1997; Ward, 1987) consider planning for a future succession to be an important question for the firm, other studies show that few firms express that they have a written plan for it (Dennis, 2005). Many smaller firms do not have written plans at all (Wijewardena et al., 2004). However, this does not mean that they do not plan. Planning can very well be done without putting it into writing. Moreover, Klein (2004) shows that it is important that the planning is teamwork, suggesting that it is important that both the incumbent and the successor are involved in the planning process. This is only likely to be happening when the incumbent 
leader is positive towards succession planning. The arguments presented above can be expressed in the following hypotheses:

H2a In family firms where the incumbent leader has a more positive attitude to planning a transition of leadership, the process before the transition is more successful.

$\mathrm{H} 2 \mathrm{~b}$ In family firms where the incumbent leader has a more positive attitude to planning a transition of leadership, the firm's post-transition performance is higher.

\section{Norm of the family concerning succession}

A norm reflects a person's individual apprehension concerning for example the norms within the nearest family about the expectations on the individual. The norm also reflects whether he/she considers the family opinion to be important and how much he/she adjusts the behaviour or intentions to what other individuals do or think. A single individual's attitude is in some way influenced by the other individuals' attitude. In this study, the norm will be expressed by the opinion held in the family about participating in succession-related questions.

When looking at family participation, there are several aspects that can affect the success of the succession. According to Dyer (1986), a consistent view held by the incumbent and the successor will lead to a higher probability that the process and the transition will be perceived as more successful. Handler $(1990,1992)$ also points out the importance to strengthen relations within families by building up the communication both within and between generations.

Transitions in family firms seems to be carried out in a smoother way when the successors are better prepared and the relations between the family members are built upon trust and compassion (Morris et al., 1997). Their opinion is that trust within a family affects to what extent the individuals within the family firm consider there is an open communication in the firm. Open communications make it possible to discuss if the firm should carry out another leadership transition and who the next possible leader should be. According to Lansberg (1988) it is important to work with communication between family members to reduce the risk of conspiracy within the family and consolidate the planning for succession in family firms. This discussion above leads to two hypotheses:

H3a In family firms with a higher level of family participation in leadership transition questions, the process before the transition is more successful.

H3b In family firms with a higher level of family participation in leadership transition questions, the firm's post-transition performance is higher.

\section{Perceived behavioural control}

The third dimension influencing the intention to carry out an action is perceived behavioural control. This dimension influences the performance both directly and indirectly. The perceived behavioural control is in this study viewed both from the incumbent's perspective and from the successor's perspective. As mentioned, both parties play an important role for a successful succession. The factor concerning the incumbent 
is expressed by his/her ability to transfer the leadership and the two factors concerning the successor are expressed by his/hers level of self-efficacy and ability to assume leadership.

\section{Perceived behavioural control of the incumbent concerning succession}

Family firms are according to Feltham et al. (2005) highly depending on the founder. A big family firm has more employees involved in the managing the firm and the dependence become less important as the firm grows and the founder gets older and soon will retire. The firm will be dependent of the founder as long as no successor is selected or if the succession process has not begun at all. It is important that the incumbent is aware of how much time the succession process will require and that the process is initiated in good time before the leadership should be transferred to the successor.

A specific timetable for the succession process, a progress for development of leadership and also attention to keep to the agreed plan are important factors for a rational succession process and final transition of leadership. It is also important that the incumbent is involved and assumes responsibility in the process of creating a plan for the succession (Moores and Barrett, 2002; Sharma et al., 2001; Ward, 1987).

The degree of awareness - by the individuals involved in the succession process and the leadership-transition - concerning both the different activities in the process and that the decision should mature during a longer time influence the expectations as well as the perceived behavioural control. Zhang and Rajagopalan (2004) point out that a stepwise transition where the incumbent and the successor has been working together parallel in the firm and where the incumbent has introduced the successor as the new leader of the firm has a positive effect on the firms post-transition success.

During the succession process the incumbent can remain in the family firm and have a partial management responsibility (Handler, 1990) and give the successor support while the leadership gradually will be passed to the successor. The transfer of experience of leadership, authority, fairness, and power to make decisions is important for the process. Based on the discussion above the following hypotheses are put forward:

H4a In family firms where the incumbent leader has a higher level of perceived behaviour control concerning the ability to transfer leadership, the process before the transition is more successful.

H4b In family firms where the incumbent leader has a higher level of perceived behaviour control concerning the ability to transfer leadership; the firm's posttransition performance is higher.

\section{Perceived behavioural control of the successor concerning succession}

Two specific factors in the dimension perceived behavioural control are closely related to the successor, namely overall self-efficacy regarding the transition and ability to actually assume leadership. Self-efficacy can be described as the individual's belief in their ability to organise and carry out actions needed in a specific situation (Bandura, 1995). Individuals' belief in their own ability - self-efficacy - affects the action in different situations, how intensively they choose to be in a given situation and for how long they will try to carry out a mission depending on the obstacles and failures that emerges. In other words, the personal belief in his/her capability is a key factor when it comes to the 
individual's action. An assumption in this study is that if the individual does not believe that he/she has the capability to carry out a leadership transition from start to finish the outcome will be dismal.

Experience is an effective way to create strong self-efficacy. Success builds a robust belief in one's self-efficacy and failure undermines it (Bandura, 1995). This is inline with Sharma (2004) who has pointed out that the successor's experience is one factor influencing both the succession process and the leadership transition. An individual's experience can be a result of theoretical education or practical application, either within the family firm as he/she will be the new leader of or within another firm.

The experiences successors will obtain by employment in other firms are according to Ward (1987) an asset for the family firm. Leaders who have taken active part in managing other firms will probably have an insight both in different styles of managing a firm and have knowledge of how these styles affect the organisation. They could also create new networks valuable for them in their role as a successor in the family firm.

Thus, self-efficacy concerns the successor's belief in abilities that are necessary for the succession process to function well - from being able to bring the matter to attention through having a good process to being able to become the new leader of the firm. The following hypotheses express the discussion above:

H5a In family firms where the successor has a higher level of self-efficacy concerning the leadership transition process, the process before the transition is more successful.

H5b In family firms where the successor has a higher level of self-efficacy concerning the leadership transition process, the firm's post-transition performance is higher.

Above, in the discussion leading up to Hypotheses $4 \mathrm{a}$ and $4 \mathrm{~b}$, we argued that it is important that the incumbent leader is able to transfer the leadership. Since a transfer only can be successful if there is a receiver, the ability of the successor to assume the leadership seems important. Earlier studies have shown a link between well carried-out transitions and well prepared successors (Sharma, 2004; Morris et al., 1997). As indicated above, ability to assume leadership is mainly about a very specific point in time where power is transferred from the incumbent to the successor and not about the process leading up to this point. Even though a good process is believed to be helpful, the actual ability to assume leadership from the incumbent seems to be of great importance. The following hypotheses can be used to express the discussion above:

H6a In family firms where the successor has a higher level of perceived behaviour control concerning ability to assume leadership, the process before the transition is more successful.

H6b In family firms where the successor has a higher level of perceived behaviour control concerning ability to assume leadership, the firm's post-transition performance is higher.

The six pairs of hypotheses discussed above are displayed in Figure 1 below. 
Figure 1 Path model and hypotheses discussed in the theoretical framework

DIMENSION

RESULT

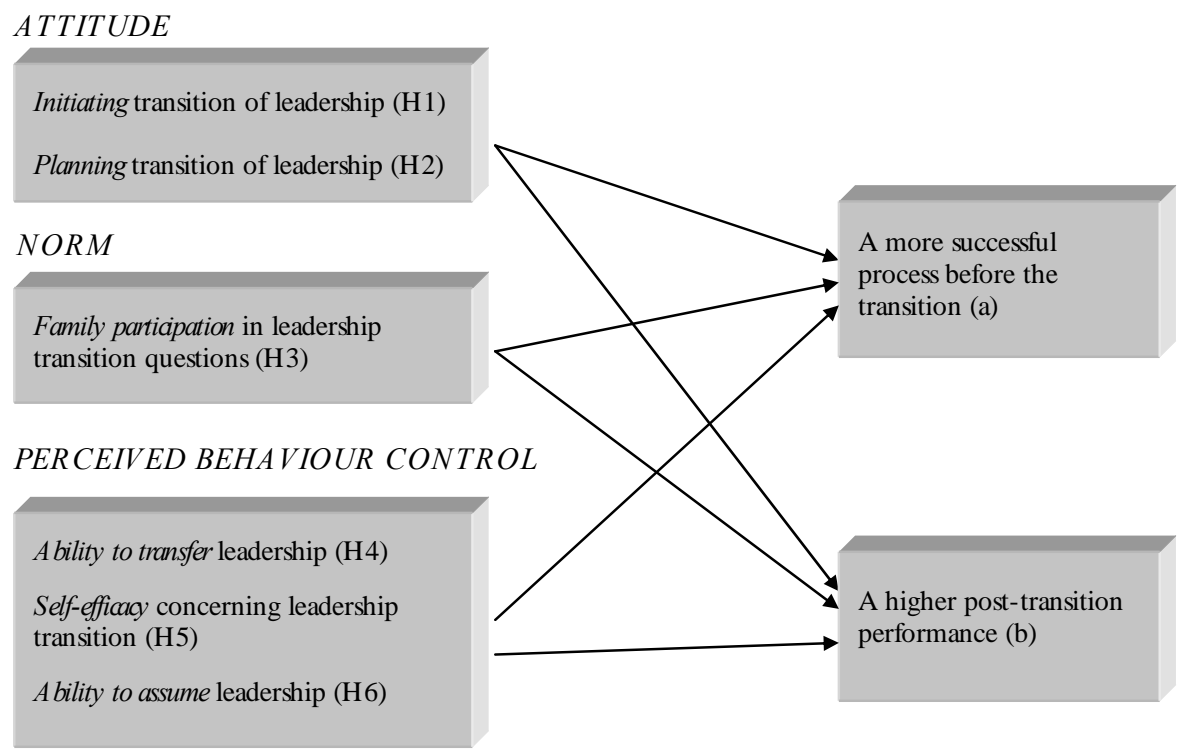

\section{Research methodology}

\subsection{Data collection}

To test the hypotheses put forward in the last section, a survey was carried out among 1100 randomly selected small Swedish firms with 10-49 employees (where the size span is based on the common EU definition of small firms). For this purpose we used the Swedish database 'Affärsdata', which includes all ltd. firms that operate in Sweden. After two reminders, we had useful responses from 338 firms (34\%). Among these, there were 156 family firms and 182 non-family firms. Among the 156 family firms, there were 60 family firms that had carried out at least one succession and in 55 of these 60 family firms the leader had assumed the leadership from a parent.

A majority of the firms (35) had carried out only one succession. It was 13 firms that has carried out two successions, ten firms had carried out three successions. The other two firms had carried out four and five successions, respectively.

Regarding industry, most of the 55 firms that had carried out a succession belong to the agriculture, hunting and forestry sector (42\%), manufacturing sector (20\%), transport, storing and communication sector (11\%), miscellaneous services, (13\%) and other sectors (13\%).

In Table 1, we show some descriptive statistics for the 55 firms in our study. The firms are representative for the sample in all variables tested (employees, turnover, age and financial ratios) except for solidity (equity/total assets ratio), where the firm in our study have a somewhat stronger solidity than firms in the population. 
Table 1 Statistics for the 55 firms

\begin{tabular}{lcc}
\hline & Mean & $\sigma$ \\
\hline Turnover (million SEK) & 46 & 59 \\
Number of employees & 18.6 & 8.1 \\
Solidity (\%) & 40.3 & 24.8 \\
Firm age (years) & 56 & 37 \\
Successor age (years) & 48 & 10 \\
\hline
\end{tabular}

\subsection{Measurements}

The questionnaire was constructed based on the literature, but for many concepts we had to come up with new questions, since appropriate scales were not found. Factor analysis (PCA using varimax or oblimin rotation, depending on whether correlations between factors were likely) was used to combine the separate questions in the questionnaire into factors. The six independent factors that have been used in the two models are

- two factors measuring the incumbent's attitude to initiating and planning the succession

- $\quad$ one factor measuring the family norm regarding family participation in questions concerning the leadership transition

- $\quad$ one factor measuring the behavioural control of the incumbent in relation to ability to transfer leadership

- two factors measuring the behavioural control of the successor, namely self-efficacy in the transfer process and ability to assume the leadership responsibility.

The inspiration to the statements measuring the incumbent's attitude to initialise (three items, $\alpha=0.88$ ) and plan (two items, $\alpha=0.86$ ) the transition comes from earlier studies showing the importance of initiating and planning transitions (Dennis, 2005; Kets de Vries, 1993; Klein, 2004; Lansberg, 1988). Turning to the family norm, we got the main inspiration to this measure (three items ${ }^{1}, \alpha=0.74$ ) from the discussions we had with the past and present leader in a small family firm. Especially the younger leader pointed out the importance of respect for the older generation's opinions and that it is important to have a good communication regarding the leadership transition in the firm. The behaviour control of the incumbent to transfer leadership (three items, $\alpha=0.77$ ) and the behavioural control of the successor to assume leadership (three items, $\alpha=0.77$ ) are inspired by earlier studies pointing on the importance for both the incumbent and the successor to take responsibility during a succession process (Moores and Barrett, 2002; Sharma et al., 2003a, 2003b; Ward, 1987). The behavioural control of the successor in terms of transition self-efficacy (three items, $\alpha=0.84$ ) is based on Sharma (2004), noting the importance of having the necessary experience and skills for the transition, and Handler (1990) as well as Kim and DeVaney (2003) regarding the important introduction in the firm and its network by the incumbent.

To model success, we used two factors in this study. The first one was the perception whether the succession process had been successful (two items reflecting the view of the incumbent and the successor, $(\alpha=0.85)$, while the second was the firm's post-transition 
performance (four items reflecting an index of changes in financial and market performance since the transition and overall firm competitiveness). All scales are reflecting the mean of the included items.

\subsection{Data and model procedures}

The results in this study are based upon a classic procedure for a quantitative study. A seven-point Likert-scale has been used for most of the statements in the inquiry. The scale ranged from 'completely disagree' to 'completely agree'. The data we got from the respondents has been processed using SPSS 15.0 for windows.

To test the hypotheses we formed in the theoretical framework, we have done hierarchical regression analysis based upon the 52 usable answers. As mentioned above, there were 55 firms that had carried out a succession between parents/children. Three of them have not answered fully on any of the scales used in the analysis leading to that the largest model includes 52 firms. Further, due to missing data in specific scales linked to the three aspects attitudes, norms and behavioural control, the full model only includes 35 and 37 firms, respectively. However, an analysis comparing the included to the excluded firms indicates minimal differences on a variety of firm characteristics (employees, turnover, age, financial ratios) - only a marginally significance for solidity, where the included firms show a higher solidity. Thus, the analysed firms are overall representative for family firm successions in Sweden.

In the results we present four regression analyses. We have one regression analysis for each dimension of TpB to find relationship between variables within one of the three dimensions (i.e., attitude, norm, and behavioural control) and the dependent variable. Thereafter we have one final analysis, looking at the relation between all independent variables and the dependent variable. We will use the latter for hypothesis testing, while the former will be used as a complement when discussing the results.

\section{Empirical findings}

Table 2 shows means, standard deviations, range and correlations for the studied variables. Table 3 shows the result of the regression analysis where process success is the dependent variable ${ }^{2}$.

As can be seen, we got highly significant models in all four cases. The explanationrate ranges from acceptable in the norm model $\left(\mathrm{R}^{2}\right.$ adj. $\left.=0.19\right)$ to extraordinary for the total model $\left(\mathrm{R}^{2}\right.$ adj. $\left.=0.80\right)$. It is clear that our chosen independent variables can explain success in the process well.

Turning to the hypotheses, H1a, expressing that a more positive attitude to initiate transition of leadership is related to a more positive process performance, was not supported in this study. Initiation did not prove to be significant even when only attitudes were used as independent variables. 
Table 2 Correlation matrix for variables in analyses concerning a successful process before the transition

\begin{tabular}{|c|c|c|c|c|c|c|c|c|c|c|}
\hline & & Mean & S.D. & Range & 1 & 2 & 3 & 4 & 5 & 6 \\
\hline 1 & $\begin{array}{l}\text { A more successful } \\
\text { process before the } \\
\text { transition }\end{array}$ & 5.77 & 1.08 & $3-7$ & & & & & & \\
\hline 2 & $\begin{array}{l}\text { Initiating transition } \\
\text { of leadership }\end{array}$ & 4.68 & 1.51 & $1-7$ & $0.53 * * *$ & & & & & \\
\hline 3 & $\begin{array}{l}\text { Planning transition } \\
\text { of leadership }\end{array}$ & 4.64 & 1.51 & $1-7$ & $0.68 * * *$ & $0.87 * * *$ & & & & \\
\hline 4 & $\begin{array}{l}\text { Family participation } \\
\text { in leadership } \\
\text { transition questions }\end{array}$ & 4.58 & 1.16 & $1-7$ & $0.46 * * *$ & 0.12 & 0.19 & & & \\
\hline 5 & $\begin{array}{l}\text { Ability to transfer } \\
\text { leadership }\end{array}$ & 5.57 & 1.17 & $3-7$ & $0.67 * * *$ & $0.68 * * *$ & $0.67 * * *$ & $0.26^{*}$ & & \\
\hline 6 & $\begin{array}{l}\text { Self-efficacy } \\
\text { concerning } \\
\text { leadership transition }\end{array}$ & 5.15 & 1.20 & $2-7$ & $0.70 * * *$ & $0.42 * * *$ & $0.41 * * *$ & $0.30 *$ & $0.53 * * *$ & \\
\hline 7 & $\begin{array}{l}\text { Ability to assume } \\
\text { leadership }\end{array}$ & 4.20 & 1.15 & $2-7$ & $0.24 *$ & 0.05 & 0.11 & 0.03 & 0.09 & $0.52^{* * *}$ \\
\hline
\end{tabular}

Notes: $* \mathrm{p}<0.10,{ }^{* *} \mathrm{p}<0.05,{ }^{* * *} \mathrm{p}<0.01$, two-tailed tests.

$\mathrm{H} 2 \mathrm{a}$, stating that a more positive attitude to planning is positively related to process performance was strongly supported. Overall, this relation has the strongest coefficient. Regarding H3a, linking a family norm of participation to process performance, we got some support. In the model where only norms are included, it proves significant, but in the full model it is on the verge of being significant. H4a, where we hypothesised that the ability of the incumbent to transfer the leadership would be linked to process performance, was supported. Both in the behavioural control model and the full model this relationship is significant. When looking at the successor, the linkage between transition self-efficacy and process performance as stated in H5a is highly significant. In the full model it is also the strongest of the three behavioural control variables. Finally, H6a, linking the successors ability to assume leadership to process performance was not supported. The relationship is not significant in the behavioural control model and in fact negative in the full model.

Next, we will turn to the other dependent variable in this study, namely post-transition performance. Table 4 shows means, standard deviations, range and correlations for the studied variables, while Table 5 shows the result of the regression analysis where post-transition success is the dependent variable. 
Table 3 Results of regression analyses concerning a successful process before the transition

\begin{tabular}{|c|c|c|c|c|c|}
\hline \multirow{2}{*}{\multicolumn{2}{|c|}{ A more successful process before the transition }} & Block 1 & Block 2 & Block 3 & Total \\
\hline & & (A) & $(N)$ & $(P B K)$ & \\
\hline & $N$ & 51 & 41 & 52 & 37 \\
\hline \multirow{4}{*}{$\begin{array}{l}\text { Attitudes } \\
\text { (A) }\end{array}$} & Initiating transition of leadership & 0.10 & & & -0.11 \\
\hline & & $(0.16)$ & & & $(0.13)$ \\
\hline & Planning transition of leadership & $0.61^{* * *}$ & & & $0.40 * *$ \\
\hline & & $(0.15)$ & & & $(0.12)$ \\
\hline \multirow{2}{*}{$\begin{array}{l}\text { Norm } \\
\text { (N) }\end{array}$} & Family participation in leadership & & $0.48 * * *$ & & $0.14^{\mathrm{a}}$ \\
\hline & transition question & & $(0.15)$ & & $(0.08)$ \\
\hline \multirow{6}{*}{$\begin{array}{l}\text { Perceived } \\
\text { behaviour } \\
\text { control } \\
(\mathrm{PBK})\end{array}$} & Ability to transfer leadership & & & $0.36 * * *$ & $0.20 * *$ \\
\hline & & & & $(0.10)$ & $(0.09)$ \\
\hline & Self-efficacy concerning leadership & & & $0.48 * * *$ & $0.35^{* * *}$ \\
\hline & transition & & & $(0.11)$ & $(0.09)$ \\
\hline & Ability to assume leadership & & & -0.06 & $-0.14 *$ \\
\hline & & & & $(0.10)$ & $(0.08)$ \\
\hline \multicolumn{2}{|l|}{ F-ratio } & 21.52 & 10.62 & 26.61 & 25.02 \\
\hline \multicolumn{2}{|l|}{$\mathrm{R}$ square } & 0.47 & 0.21 & 0.62 & 0.83 \\
\hline \multicolumn{2}{|c|}{ R square adj. } & 0.45 & 0.19 & 0.60 & 0.80 \\
\hline \multicolumn{2}{|c|}{ Significance } & $<0.001$ & $<0.001$ & $<0.001$ & $<0.001$ \\
\hline
\end{tabular}

Notes: ${ }^{*} \mathrm{p}<0.10,{ }^{* *} \mathrm{p}<0.05,{ }^{* * *} \mathrm{p}<0.01$, $\mathrm{p}$ values are two-tailed.

Unstandardised path-coefficients shown in table. Standard errors within parentheses. $^{\mathrm{a}}=$ almost significant $(10.6 \%)$.

Table 4 Correlation matrix for variables in analyses concerning a higher post-transition performance

\begin{tabular}{|c|c|c|c|c|c|c|c|c|c|c|}
\hline & & Mean & S.D. & Range & 1 & 2 & 3 & 4 & 5 & 6 \\
\hline 1 & $\begin{array}{l}\text { A higher } \\
\text { post-transition } \\
\text { performance }\end{array}$ & 0.71 & 0.94 & -1 to 2 & & & & & & \\
\hline 2 & $\begin{array}{l}\text { Initiating transition } \\
\text { of leadership }\end{array}$ & 4.68 & 1.51 & $1-7$ & 0.03 & & & & & \\
\hline 3 & $\begin{array}{l}\text { Planning transition } \\
\text { of leadership }\end{array}$ & 4.64 & 1.51 & $1-7$ & -0.08 & $0.87^{* * *}$ & & & & \\
\hline 4 & $\begin{array}{l}\text { Family participation } \\
\text { in leadership } \\
\text { transition questions }\end{array}$ & 4.58 & 1.16 & $1-7$ & -0.04 & 0.12 & 0.19 & & & \\
\hline 5 & $\begin{array}{l}\text { Ability to transfer } \\
\text { leadership }\end{array}$ & 5.57 & 1.17 & $3-7$ & $0.23^{\mathrm{a}}$ & $0.68 * * *$ & $0.67 * * *$ & $0.26^{*}$ & & \\
\hline 6 & $\begin{array}{l}\text { Self-efficacy } \\
\text { concerning } \\
\text { leadership transition }\end{array}$ & 5.15 & 1.20 & $2-7$ & 0.01 & $0.42 * * *$ & $0.41^{* * *}$ & $0.30^{*}$ & $0.53 * * *$ & \\
\hline 7 & $\begin{array}{l}\text { Ability to assume } \\
\text { leadership }\end{array}$ & 4.20 & 1.15 & $2-7$ & -0.06 & 0.05 & 0.11 & 0.03 & 0.09 & $0.52 * * *$ \\
\hline
\end{tabular}


Table 5 Results of regression analyses concerning a higher post-transition performance

\begin{tabular}{|c|c|c|c|c|c|}
\hline \multirow{2}{*}{\multicolumn{2}{|c|}{ A higher post-transition performance }} & \multirow{2}{*}{$\frac{\text { Block } 1}{\text { (A) }}$} & \multirow{2}{*}{$\frac{\text { Block } 2}{(N)}$} & \multirow{2}{*}{$\frac{\text { Block } 3}{(P B K)}$} & \multirow[t]{2}{*}{ Total } \\
\hline & & & & & \\
\hline & $N$ & 47 & 36 & 46 & 35 \\
\hline \multirow{4}{*}{$\begin{array}{l}\text { Attitudes } \\
\text { (A) }\end{array}$} & \multirow{2}{*}{$\begin{array}{l}\text { Initiating transition of } \\
\text { leadership }\end{array}$} & 0.22 & & & 0.15 \\
\hline & & $(0.20)$ & & & $(0.26)$ \\
\hline & \multirow{2}{*}{$\begin{array}{l}\text { Planning transition of } \\
\text { leadership }\end{array}$} & -0.24 & & & -0.35 \\
\hline & & $(0.19)$ & & & $(0.24)$ \\
\hline \multirow{2}{*}{$\begin{array}{l}\text { Norm } \\
\text { (N) }\end{array}$} & \multirow{2}{*}{$\begin{array}{l}\text { Family participation in } \\
\text { leadership transition } \\
\text { question }\end{array}$} & & -0.04 & & -0.02 \\
\hline & & & $(0.15)$ & & $(0.16)$ \\
\hline \multirow{6}{*}{$\begin{array}{l}\text { Perceived } \\
\text { behaviour } \\
\text { control } \\
\text { (PBK) }\end{array}$} & \multirow{2}{*}{$\begin{array}{l}\text { Ability to transfer } \\
\text { leadership }\end{array}$} & & & $0.30 *$ & $0.33 *$ \\
\hline & & & & $(0.15)$ & $(0.19)$ \\
\hline & \multirow{2}{*}{$\begin{array}{l}\text { Self-efficacy concerning } \\
\text { leadership transition }\end{array}$} & & & -0.13 & -0.05 \\
\hline & & & & $(0.16)$ & $(0.18)$ \\
\hline & \multirow{2}{*}{$\begin{array}{l}\text { Ability to assume } \\
\text { leadership }\end{array}$} & & & -0.01 & 0.06 \\
\hline & & & & $(0.14)$ & $(0.15)$ \\
\hline \multicolumn{2}{|l|}{ F-ratio } & 0.78 & 0.07 & 1.35 & 0.83 \\
\hline \multicolumn{2}{|l|}{$\mathrm{R}$ square } & 0.03 & $<0.01$ & 0.09 & 0.15 \\
\hline \multicolumn{2}{|c|}{ R square adj. } & -0.01 & -0.03 & 0.02 & -0.03 \\
\hline \multicolumn{2}{|l|}{ Significance } & 0.47 & 0.80 & 0.27 & 0.56 \\
\hline
\end{tabular}

Notes: $* \mathrm{p}<0.10$ (two-tailed).

Unstandardised path-coefficients shown in table.

Standard errors within parentheses.

As can be seen, it is rather easy to sum up the results pertaining to post-transition performance. All hypotheses except one turned up non-significant. Only H4b, linking ability to transfer leadership to post-transition performance shows an apparent significant result. However, since the overall model is not significant, it is not wise to infer anything from it. Thus, we can conclude that there are no significant results for the relation between our studied variables and post-transition performance.

Based upon the results presented above we find it interesting to analyse if there is any relation between if the process has been successful and the post-transition performance. An analysis of this relation does not indicate any relation between the two variables. Thus, our two dependent variables are independent. In Figure 2 we show the relations confirmed by the results of our study. 
Figure 2 Results concerning relations for the process and post-transition model



\section{Discussion, conclusions and implications}

Let us first look at some important limitations before discussing the results. First, our empirical information is based on about 50 Swedish small family firms that have carried out at least one succession. Even if 50 is a large enough sample for drawing general conclusions, it would of course be better if we had a larger sample. Still, since we started with a random sample of more than 1000 firms, it would be a costly process to get more established successions drawn from a random population. Given the reasonable response rate (38\%) and the fact that it is virtually impossible to sample family firms and especially those who have carried out successions directly, our sample seems appropriate. Second, many of the scales we use are not validated by earlier studies. This is of course due to that we could not find appropriate scales in the literature for our model and context, as is often the case for novel approaches. Still, since factor structures and alpha-values were appropriate, and the model as a whole worked well, we have indications that our operationalisations are useful. Third, our use of one single informant (the present CEO which is the successor in our model) may be a problem. It would have been better if we could have had the former CEO (i.e., the incumbent in our model) as an informant also. However, this would have led to a lower number of usable cases, based on at least three scenarios:

1 the former CEO may not be able to answer questions (e.g., too old or deceased) 
2 the former CEO is unwilling to answer questions

3 the present CEO is unwilling to answer questions given that he knows that the old CEO answers similar questions.

Since we already have a sample that is in the lower region of the acceptable range, the risk of having multiple informants overshadows the potential benefits.

Turning to the results, we will now discuss some aspects that we find especially interesting. These are

1 the overall performance of the model for our two chosen dependent variables

2 elaboration on some mechanisms in the process model.

From the results it is clear that we are able to explain what makes a successful succession in terms of process but not in terms of outcome. For process, i.e., satisfaction with the way the transition was carried out, our chosen explanatory variables account for $80 \%$ of the variation, which is excellent. The same variables are however unrelated to the results of the succession, i.e., whether the firm is more competitive with the new leader compared to the old. One reason for this may be that it has been found that family firms performs worse during transition periods (Bennedsen et al., 2007). A good succession process is often linked to an extended period from initiation to a completed transition. Then the positive aspects of having a good process would be outbalanced by a negative impact from having a longer transition. However, having a good process could also be linked to better performance in the longer run. Milton (2008) argues that it is the 'familiness' of the family firm that leads to competitive advantages in relation to other firms. From this perspective, a good process would be important to preserve and perhaps develop the familiness. It is perhaps not unexpected that our variables would be better to explain process than outcome. After all, the variables are closer linked to aspects related to the succession as such and therefore to the process. Still, the difference between an almost perfect explanation as compared to no explanation at all was unexpected. A possible reason to this unexpected difference could be that even if the successor has the perception that the succession process has been good it doesn't automatically mean that he/she has the same positive perception about the outcome. There are probably other things that influence the perception of outcome. It doesn't matter how much support and how good the introduction of the new leader has been when it comes to outcome. There are perhaps other leader skills than those we have measured that make for a thriving firm.

The above pattern demonstrates clearly the importance of having adequate dependent variables in the study. If we only would have been interested in the final outcome of a family firm succession, we would say that Ajzen's TpB is not appropriate for this context. Alternatively, we would question our conceptualisation of the theory and/or the operationalisations of this conceptual framework. On the other hand, if we had only looked at the process, overconfidence is likely to occur. If we only had one chosen dependent variable and this could be almost fully explained by the dependent variables, it would be tempting to advise everybody to use Ajzen's theory. With our mixed results, we can provide a more nuanced view, where it is clear that Ajzen's theory is very promising for understanding process-near outcomes in small family firm successions, but dismal for outcomes farther away from the actual process of handing over the leadership from one generation to the next. Since our two dependent variables are extremes, it would be interesting to study other dependent variables that conceptually would be between 
'succession process' and 'firm outcome'. This could perhaps be outcomes that are more family firm oriented, such as the CEOs commitment to making the firm survive and preparing for the next succession.

Since the model concerning relations to a successful process has a very high explanation rate (83\%), we have a strong basis for our conclusions about the process. Virtually all variance can be explained by the three dimensions we suggested based on Ajzen's theory. As indicated above, this lends support to Ajzen's theory and it is clear that it can be used in the context of small family firm succession process. The assertion by other authors (Moores and Barrett, 2002) that other family members, external leaders, members of the board and perhaps external owners also may be important for a successful succession is thus not the case in our study.

Turning to the individual factors, it was not especially surprising that a more positive attitude to planning has a relation to a more successful process. Earlier research has pointed out the lack of planning as one reason for difficulties to carry out more than one transition in family firms (Emling, 2000; Gersick et al., 1997; Ward, 1987). However, as some studies point out (see, Wijewardena et al., 2004), we should be aware of that planning does not have to be a formal plan. In smaller firms plans can occur in other forms than a written one.

As can be seen by the results, norms can explain process performance by itself to some degree, but when attitudes and behavioural control is also added to the model, the explanatory power is lost. This means that a large part of the explanatory power from norms is shared with attitudes and behavioural control. Thus, norms are important, but in this context the positive influence of them works through attitudes and behavioural control. The final dimension, which was related to behavioural control, turned out to be strongest in explaining process performance. The ability of the incumbent to do a formal handover and the self-efficacy of the successor are thus critical for a successful succession.

The factors related to behavioural control turned out to be the strongest followed by the attitude factors. One conclusion from the results is that factors related both to the incumbent and the successor is important. Since the factors have to do with ability to transfer and transition self-efficacy, our results clearly indicate that the two generations need to collaborate in the transition process for it to become successful. The reason why the successors ability to assume leadership did not prove helpful in the model could be related to the fact that the concept is too much oriented towards a passive role of the incumbent. Another possible explanation to the marginal impact could be that the measuring variables are related to assuming the leadership in a very concrete way. A transition managed by the incumbent in a way that gives the successor a positive experience probably strengthens the successor's self-efficacy, which was found to be a key to making the process successful. The need for having a balance between the two main actors has also been pointed out before as an important prerequisite for a successful succession. Sharma et al. (2003a) and also Handler (1990) note that both the incumbent and the successor need to be active during the process and that the formal transition should be carried out gradually.

Based on the correlation analysis it is clear that all significant factors inter-correlate. Thus, it is likely that these factors influence each other in a complex fashion that we are not able to untangle properly unless we follow up this study and get a longitudinal design where causality can be addressed. For now, we can only theorise about possible links between the factors. For example, a more positive attitude towards planning is probably 
useful when it comes to working with the actual transfer of leadership. It is also likely that a well performed transition from the perspective of the incumbent will give good chances for the successor to build his or her self-efficacy. Moreover, it is also likely that there will be linkages from one succession process to the next. For instance, if the successor has better self-efficacy regarding transition related aspects when starting his or her tenure, it is likely that this will lead to a more positive attitude to initiating and planning for the next.

In sum, our results show that our framework can be used to model the success in the succession process but not the post-transition performance. When looking at process it seems as we have a very good base in our model and we encourage future researchers to use the overall framework in other contexts. However, when it comes to post-transition performance future research must develop better models with a different framework.

\section{References}

Ajzen, I. (1991) 'The theory of planned behavior', Organizational Behavior and Human Decision Processes, Vol. 50, pp.179-211.

Bandura, A. (1995) 'Exercise of personal and collective efficacy in changing societies', IA. Bandura (Ed.): Self-Efficacy in Changing Societies, Cambridge University Press, New York.

Bennedsen, M., Nielsen Meisner, K., Perez-Gonzalez, F. and Wolfenzon D. (2007) 'Inside the family firm: the role of families in succession decisions and performance', The Quarterly Journal of Economics, Vol. 122, No. 2, pp.647-691.

Bridge, S., O’Neill, K. and Cromie, S. (1998) Understanding Enterprise, Entrepreneuship \& Small Business, MacMillan Press Ltd., Hampshire, England.

Dennis, A. (2005) 'Succession-planning dos and dont's', Journal of Accountancy, Vol. 199, No. 2, pp.47-50.

Dyck, B., Mauws, M., Starke, F.A. and Mischke, G.A. (2002) 'Passing the baton, the importance of sequence, timing, technique and communication in executive succession', Journal of Business Venturing, Vol. 17, No. 2, pp.143-162.

Dyer, W.G., Jr. (1986) Cultural Change in Family Firms: Anticipating and Managing Business and Family Transitions, Jossey-Bass, San Fransisco, California.

Emling, E. (2000) Svenskt Familjeföretagande, Elanders Gotab, Stockholm.

Feltham, T.S., Feltham, G. and Barnett, J.J. (2005) 'The dependence of family businesses on a single decision-maker', Journal of Small Business Management, January, pp.1-15.

Fox, M., Nilikant, V. and Hamilton, R.T. (1996) 'Managing succession in family-owned businesses’, International Small Business Journal, Vol. 15, No. 1, pp.15-25.

Gersick, K.E., Davis, J.A., McCollom Hampton, M. and Lansberg, I. (1997) Generation to Generation: Life Cycles of the Family Business, Harvard Business School Press, Boston.

Hall, A. (2003) Strategising in the Context of Genuine Relations, An Interpretative Study of Strategic Renewal Through Family Interaction, Jönköping International Business School. Jönköping.

Handler, W.C. (1990) 'Succession in family firms: a mutual role adjustment between entrepreneur and next-generation family members', Entrepreneurship Theory and Practice, Vol. 15, No. 1, pp.37-51.

Handler, W.C. (1992) 'The succession experience of the next generation', Family Business Review, Vol. 5, No. 3, pp.283-307.

Hubler, T. (1999) 'Ten most prevalent obstacles to family-business succession planning', Family Business Review, Vol. 12, No. 2, pp.117-122. 
Kets de Vries, M.F.R.H. (1993) 'The dynamics of family controlled firms: the good and the bad news’, Organizational Dynamics, Vol. 21, No. 3, pp.59-71.

Kim, H. and DeVaney, S.A. (2003) 'The expectation of partial retirement among family business owners', Family Business Review, Vol. 16, No. 3, pp.199-210.

Klein, R. (2004) 'Strategic facilities planning: keeping an eye on the long view', Journal of Facilities Management, Vol. 2, No. 4, pp.338-350.

Lansberg, I. (1988) 'The succession conspiracy', Family Business Review, Vol. 1, No. 2, pp.119-143.

Lansberg, I. (1999) Succeeding Generations: Realizing the Dream of Families in Business, Harvard Business School Press, Boston, Massachusetts.

Le Breton-Miller, I., Miller, D. and Steier, L.P. (2004) 'Toward an integrative model of effective FOB succession', Entrepreneurship Theory and Practice, Vol. 28, No. 4, pp.305-328.

Lee, M-S. and Rogoff, E.G. (1996) 'Research note: comparison of small businesses with family participation versus small businesses without family participation: an investigation of differences in goals, attitudes, and family/business conflict', Family Business Review, Vol. 9, No. 4, pp.423-437.

Miller, D., Steier, L. and Le Breton-Miller, I. (2003) 'Lost in time: intergenerational succession, change, and failure in family business', Journal of Business Venturing, Vol. 18, No. 4, pp.513-531.

Milton, L.P. (2008) 'Unleashing the relationship power of family firms: identity confirmation as a catalyst for performance', Entrepreneurship Theory and Practice, Vol. 32, No. 6, pp.1063-1081.

Moores, K. and Barrett, M. (2002) Learning Family Business: Paradoxes and Pathways, Ashgate, Aldershot.

Morris, M.H., Williams, R.O., Allen, J.A. and Avila, R.A. (1997) 'Correlates of success in family business transitions', Journal of Business Venturing, Vol. 12, No. 5, pp.385-401.

Neubauer, F. and Lank, A.G. (1998) The Family Business: Its Governance for Sustainability, Macmillan, Basingstoke.

NUTEK (2004) Generationsskiften i Företag - En Problemanalys, B 2004:2.

O’Brien, R.M. (2007) 'A caution regarding rules of thumb for variance inflation factors', Quality and Quantity, Vol. 41, No. 5, pp.673-690.

Sharma, P. (2004) 'An overview of the field of family business studies: current status and directions for the future', Family Business Review, Vol. 17, No. 1, pp.1-36.

Sharma, P., Chrisman, J.J., Pablo, A.L. and Chua, J.H. (2001) 'Determinants of initial satisfaction with the succession process in family firms: a conceptual model', Entrepreneurship Theory and Practice, Vol. 25, No. 3, pp.17-35.

Sharma, P., Chrisman, J.J. and Chua, J.H. (2003a) 'Predictors of satisfaction with the succession process in family firms', Journal of Business Venturing, Vol. 18, No. 5, pp.667-687.

Sharma, P., Chrisman, J.J. and Chua, J.H. (2003b) 'Succession planning as planned behavior: some empirical results’, Family Business Review, Vol. 16, No. 1, pp.1-15.

Venter, E., Boshoff, C. and Maas, G. (2005) 'The influence of successor-related factors on the succession process in small and medium-sized family businesses’, Family Business Review, Vol. 18, No. 4, pp.283-303.

Ward, J.L. (1987) Keeping the Family Business Healthy, Jossey-Bass, San Fransisco, California.

Wijewardena, H., De Zoysa. A., Fonseka, T. and Perera, B. (2004) 'The impact of planning and control sophistication on performance of small and medium-sized enterprises: evidence from Sri Lanka’, Journal of Small Business Management, Vol. 42, No. 2, pp.209-217.

Zhang, Y. and Rajagopalan, N. (2004) 'When the known devil is better than an unknown god: an empirical study of the antecedents and consequences of relay CEO successions', Academy of Management Journal, Vol. 47, No. 4, pp.483-500. 


\section{Notes}

1 The final measure is an average of the successor's own view, the general view of the older generation and if applicable the general view of the younger generation.

2 As can be noted, correlations are overall rather high, where the highest is found for the correlation between the two attitudes. Tests to determine problems with multicolinearity (VIF) show no problems for Blocks 1 to 3 where the highest value is for Block 1 (VIF $=4.0$ ) which is under the cut-off of 5.0 (O'Brien, 2007). For the total model the value is slightly above the cut-off $(\mathrm{VIF}=5.5)$. However, when running the model without the initiating variable, the same general results are produced and all VIF-values are clearly below the cut-off. 